\title{
Pengaruh Pendekatan Pembelajaran Matematika Realistik dan Saintifik terhadap Prestasi Belajar, Kemampuan Penalaran Matematis dan Minat Belajar
}

\author{
Aji Wibowo \\ SMP Negeri 1 Kelumpang Hilir. Jalan A. Yani km 294, Desa Tegalrejo, Kec. Kelumpung Hilir, Kab. \\ Kota Baru, Kalimantan Selatan, 72182, Indonesia \\ Email: ajiwibowo471@yahoo.com \\ Received: 19 July 2016; Revised:5 May 2017; Accepted: 8 May 2017
}

\begin{abstract}
Abstrak
Penelitian ini bertujuan untuk mendeskripsikan pengaruh pendekatan pembelajaran realistik dan saintifik terhadap prestasi belajar, kemampuan penalaran matematis, dan minat belajar. Jenis penelitian ini adalah quasi experiment dengan pretest-posttest nonequivalent group design. Sampel penelitian adalah tiga kelas yang dipilih secara acak dari enam kelas yang ada. Instrumen yang digunakan adalah tes prestasi belajar, tes kemampuan penalaran matematis, dan angket minat belajar. Untuk menguji keefektifan pendekatan pembelajaran realistik dan saintifik serta pembelajaran konvensional menggunakan uji $t$ one sample. Hasil penelitian menunjukkan bahwa pendekatan pembelajaran matematika realistik efektif terhadap prestasi belajar, kemampuan penalaran matematis, dan minat belajar; pendekatan pembelajaran saintifik efektif terhadap prestasi belajar dan minat belajar tetapi tidak efektif terhadap kemampuan penalaran matematis; sedangkan pembelajaran konvensional tidak efektif terhadap prestasi belajar, kemampuan penalaran matematis, dan minat belajar. Pendekatan pembelajaran realistik dan saintifik memberikan berpengaruh yang lebih efektif dibandingkan dengan pembelajaran konvensional terhadap prestasi belajar, kemampuan penalaran matematis, dan minat belajar. Pendekatan pembelajaran realistik lebih efektif daripada pendekatan saintifik terhadap prestasi belajar kemampuan penalaran matematis, dan minat belajar.
\end{abstract}

Kata Kunci: Pendekatan realistik, pendekatan saintifik, prestasi belajar, kemampuan penalaran matematis, minat belajar

\section{The Effect of Teaching Realistic and Scientific Mathematics Approach on Students Learning Achievement, Mathematical Reasoning Ability, and Interest}

\begin{abstract}
This study aims to describe the effect of realistic and scientific approach on student's learning achievement, mathematical reasoning ability, and interest. This study is a quasi-experimental study using the pretest-posttest nonequivalent group design. The research sample was randomly selected from six classes, three classes were elected. The instrument used in this study is the learning achievement test, a test of mathematical reasoning ability, and an interest-in-learning questionnaire. To test the effectiveness of teaching realistic and scientific mathematics approach, as well as conventional teaching using one sample $t$-test. The research findings indicate that the teaching realistic mathematics approach is effective in student's learning achievement, mathematical reasoning ability, and interest; the teaching scientific approaches is effective on student's learning achievement, and interest, but is not effective on mathematical reasoning ability; whereas conventional teaching is not effective on students learning achievement, mathematical reasoning ability, and interest. The teaching realistic and scientific mathematics approach has an effect and is more effective than conventional teaching on student's learning achievement, mathematical reasoning ability, and interest. The realistic mathematics approach is more effective than a scientific approach on student's learning achievement, mathematical reasoning ability, and interest.
\end{abstract}

Keywords: realistic approach, scientific approach, academic achievement, mathematical reasoning ability, interest in learning

How to Cite: Wibowo, A. (2017). Pengaruh pendekatan pembelajaran matematika realistik dan saintifik terhadap prestasi belajar, kemampuan penalaran matematis dan minat belajar. Jurnal Riset Pendidikan Matematika, 4(1), 1-10. doi:http://dx.doi.org/10.21831/jrpm.v4i1.10066

Permalink/DOI: http://dx.doi.org/10.21831/jrpm.v4i1.10066 


\section{Jurnal Riset Pendidikan Matematika, 4 (1), 2017 - 2}

Aji Wibowo

\section{PENDAHULUAN}

Matematika memiliki peranan yang sangat penting dalam kehidupan. Berkembangnya teknologi informasi dan komunikasi sekarang ini tidak terlepas dari adanya matematika. Dengan memiliki kemampuan dalam matematika, seseorang dapat membentuk pola pikir sistematis, melakukan penalaran, membuat dugaan, mengambil keputusan secara cermat, bersikap teliti, memiliki rasa ingin tahu, kreatif, dan inovatif. Selain itu, matematika merupakan alat yang digunakan untuk mendukung ilmu-ilmu pengetahuan, baik dalam bidang sosial, ekonomi, maupun sains.

Berdasar pada pentingnya penguasaan matematika maka mata pelajaran matematika diberikan mulai dari jenjang sekolah dasar hingga sekolah menengah. Menurut Peraturan Menteri Pendidikan Nasional Nomor 22 Tahun 2006 tentang standar isi, menyatakan bahwa mata pelajaran matematika tingkat Sekolah Menengah Pertama (SMP) bertujuan agar siswa memiliki kemampuan sebagai berikut: (1) memahami konsep matematika, menjelaskan keterkaitan antar-konsep, dan mengaplikasikan konsep atau algoritma, secara luwes, akurat, efisien, dan tepat dalam pemecahan masalah; (2) menggunakan penalaran pada pola dan sifat, melakukan manipulasi matematika dalam membuat generalisasi, menyusun bukti atau menjelaskan gagasan dan pernyataan matematika; (3) memecahkan masalah yang meliputi kemampuan memahami masalah, merancang model matematika, menyelesaikan model dan menafsirkan solusi yang diperoleh; (4) mengomunikasikan gagasan dengan simbol, tabel, diagram, atau media lain untuk memperjelas keadaan atau masalah; (5) memiliki sikap menghargai kegunaan matematika dalam kehidupan, yaitu memiliki rasa ingin tahu, perhatian dan minat dalam mempelajari matematika, serta sikap ulet dan percaya diri dalam pemecahan masalah (Menteri Pendidikan Nasional, 2006).

Berdasarkan tujuan pembelajaran matematika tingkat SMP tersebut, prestasi belajar, kemampuan penalaran matematis dan minat belajar siswa merupakan kemampuan yang harus diperhatikan dalam pembelajaran matematika. Prestasi belajar merupakan bagian penting yang harus ditingkatkan dalam pendidikan, hal ini sejalan dengan Lovat, Dally, Clement, \& Toomey (2011, p. 6) yang menyatakan bahwa sejak awal 1990-an, banyak usaha yang bertujuan untuk memaksimalkan prestasi belajar siswa dalam pendidikan dan menguatkan kelemahan dari kegagalan. Prestasi yang dimaksudkan juga termasuk prestasi belajar matematika.

Prestasi merupakan hasil dari usaha-usaha untuk mencapai tujuan yang dimiliki oleh individu-individu dengan tujuan meraih kesuksesan dalam setiap tugas yang diberikan. Menurut Nitko \& Brookhart (2011, p. 497) bahwa "achievement is knowledge, skills, and abilities that students have developed as a result of instruction". Prestasi adalah pengetahuan, keterampilan, dan kemampuan yang telah dikembangkan siswa sebagai suatu hasil pembelajaran. Lebih lanjut prestasi belajar merupakan kemampuan siswa mencapai pengetahuan atau tingkat kompetensi pada mata pelajaran di sekolah yang diukur dengan tes standar yang biasanya dirancang oleh guru sebagai hasil pembelajaran.

Matematika tidak hanya berisi materi berhitung, namun juga memuat pernyataan-pernyataan benar dan salah, menyusun bukti, serta memberikan kesimpulan dari suatu pernyataan yang memerlukan kemampuan penalaran. Kemampuan penalaran matematis merupakan bagian penting dalam memahami matematika (The National Council of Teachers of Mathematics, 2009, p. 5).

Melalui pembelajaran matematika cara berpikir siswa diharapkan dapat berkembang dengan baik karena matematika memiliki struktur dan keterkaitan yang kuat dan jelas antara konsep-konsep. Demikian maka matematikan sangat memungkinkan untuk dapat meningkatkan kemampuan penalaran. Menurut The National Council of Teachers of Mathematics (2000, p. 262) bahwa, reasoning is an integral part of doing mathematics. Students should enter the middle grades with the view that mathematics involves examining patterns and noting regularities, making conjectures about possible generalizations, and evaluating the conjectures.

Pernyataan tersebut bermakna penalaran merupakan bagian yang tidak terpisahkan dari matematika. Siswa pada tingkat sekolah menengah harus berpandangan bahwa matematika melibatkan kegiatan memeriksa pola dan mencatat keteraturan, membuat dugaan tentang kemungkinan generalisasi, dan mengevaluasi dugaan.

Kemampuan penalaran matematis menurut Tipps, Johnson, \& Kennedy (2008, p. 13) memungkinkan siswa untuk (a) mengenal penalaran dan pembuktian sebagai aspek dasar dari matematika; (b) membuat dan menyelidiki 


\section{Jurnal Riset Pendidikan Matematika, 4 (1), 2017 - 3}

Aji Wibowo

dugaan matematika; (c) mengembangkan dan mengevaluasi argumen matematika dan pembuktian; (d) memilih dan menggunakan berbagai jenis metode penalaran dan pembuktian. Dalam penelitian ini kemampuan penalaran matematis meliputi: (1) menyelesaikan masalah dalam menemukan pola; (2) membuat generalisasi; (3) mengevaluasi argumen matematika.

Salah satu aspek psikologi yang dapat mendorong seseorang mencapai tujuan tertentu adalah minat. Seseorang yang memiliki minat terhadap suatu objek, cenderung memberikan perhatian yang lebih besar kepada objek tersebut (Dewey, 1975, p. 1). Ketika siswa mempunyai minat yang bagus, mereka relatif mempunyai keberhasilan diri yang tinggi dan mempunyai perhatian lebih, mempunyai tujuan dan menggunakan strategi dalam berdisiplin daripada siswa dengan minat yang kurang (Preiss \& Sternberg, 2010, p. 108). Demikian pula terjadi pada pembelajaran matematikan, minat siswa terhadap matematika menjadi salah satu faktor penting dalam menentukan keberhasilan pembelajaran matematika. Siswa yang mempunyai minat belajar matematika berarti mempunyai usaha dan kemauan untuk mempelajari matematika. Adapun aspek minat belajar siswa dalam penelitian ini adalah: (1) perhatian; (2) ketertarikan; (3) keingintahuan; (4) pilihan seseorang terhadap pembelajaran matematika.

Di antara pendekatan pembelajaran yang dapat menjadi alternatif untuk meningkatkan prestasi belajar matematika siswa, kemampuan penalaran matematis, dan minat belajar siswa adalah pendekatan matematika realistik. Gravemeijer (1994, p. 82) mengemukakan bahwa "realistic mathematics education is rooted in Freudenthal's interpretation of mathematics as an activity" pernyataan tersebut bermakna RME didasari dari pandangan Freudenthal bahwa matematika adalah aktivitas manusia. Lebih lanjut Crompton \& Traxler (2015, p. 97) "RME is an approach to mathematics education that involves students developing their understanding by exploring and solving problem set in contexts that engage their interest". RME adalah sebuah pendekatan untuk pendidikan matematika yang melibatkan siswa mengembangkan pemahaman mereka dengan mengeksplorasi dan memecahkan masalah yang ditetapkan dalam konteks yang terlibat ketertarikan siswa.

Menurut Sugiman $(2011$, p. 8) tipe realistik yang mempunyai ciri pendekatan bottomup dimana siswa mengembangkan model sendiri dan kemudian model tersebut dijadikan dasar untuk mengembangkan matematika formalnya. Ada dua macam model yang terjadi dalam proses tersebut yakni model dari situasi (model of situation) dan model untuk matematis (model for formal mathematics). Selanjutnya Hadi (2005, p. 24) mendeskripsikan proses pembelajaran dalam RME yaitu: (1) titik awal pembelajaran harus memberi pengalaman nyata bagi siswa sehingga dapat terlibat secara langsung dalam aktifitas matematika (2) untuk menampung pengetahuan matematika yang dimiliki siswa, titik awal tersebut juga harus dijelaskan berdasarkan tujuan potensial urutan belajar (learning sequence); (3) urutan pembelajaran harus melibatkan kegiatan dimana siswa membuat dan menguraikan model-model simbolik dari aktifitas matematika informal mereka (4) ketiga ajaran tersebut efektif apabila direalisasikan dalam pembelajaran interaktif (5) fenomena riil bentuk-bentuk dan konsep matematik dimanifestasikan dalam keterkaitan (intertwining) berbagai sub pokok bahasan.

Altenatif pembelajaran lainnya yang dapat meningkatkan prestasi belajar matematika siswa, kemampuan penalaran matematis, dan minat belajar siswa adalah pendekatan saintifik. Pendekatan saintifik menjadikan pembelajaran lebih aktif dan tidak membosankan. Siswa dapat mengonstruksi pengetahuan dan keterampilannya melalui fakta-fakta yang ditemukan dalam penyelidikan dilapangan guna pembelajaran. Pada pembelajaran matematika misalnya, siswa dapat diajak melihat langsung peristiwa, mengamati kejadian, fenomena, konteks atau situasi yang berkaitan dengan penggunaan bilangan bulat, seperti temperatur atau suhu berbagai benda, ketinggian pohon atau daratan, dan sebagainya.

Menurut Hosnan \& Sikumbang (2014, p. 36), pembelajaran dengan pendekatan saintifik memiliki ciri-ciri atau karakteristik: (1) berpusat pada siswa; (2) melibatkan keterampilan proses dalam menguasai konsep, hukum dan prinsip; (3) melibatkan proses-proses kognitif yang potensial dalam merangsang perkembangan intelek, khususnya keterampilan berpikir tingkat tinggi siswa; (4) dapat mengembangkan karakter siswa.

Beberapa ahli mengemukakan pendapat untuk mendefinisikan pendekatan saintifk. Scientific method menurut D'Amico \& Gallaway (2010, p. 34) memiliki beberapa tahapan yaitu: 


\section{Jurnal Riset Pendidikan Matematika, 4 (1), 2017 - 4}

Aji Wibowo

(1). State the problem; (2) gather information; (3). develop a hypothesis (A hypothesis is an interpretation of the information gathered by the scientist); (4). perform experiments to test the accuracy of the hypothesis; (5). record and analyze the data collected; (6). state a conclusion.

Pernyataan tersebut bermakna bahwa tahapan saintifik (1) menyatakan masalah; (2). mengumpulkan informasi (3). mengembangkan hipotesis (hipotesis merupakan interpretasi dari informasi yang dikumpulkan oleh ilmuwan) (4).melakukan eksperimen untuk menguji keakuratan hipotesis; (5). merekam dan menganalisa data yang dikumpulkan; (6). menyatakan kesimpulan. Adapun langkah-langkah pembelajaran dengan menggunakan pendekatan saintifik menurut Menteri Pendidikan dan Kebudayaan Republik Indonesia (2014, p. 332) terdiri dari mengamati, menanya, mengumpulkan informasi, menalar, dan mengomunikasikan.

Penelitian ini bertujuan untuk mendeskripsikan keefektifan pendekatan pembelajaran realistik, pendekatan saintifik dan pembelajaran konvensional terhadap prestasi belajar, kemampuan penalaran matematis dan minat belajar, mendeskripsikan ada tidaknya pengaruh pendekatan pembelajaran realistik dan saintifik terhadap prestasi belajar kemampuan penalaran matematis, dan minat belajar, dan mendeskripsikan perbandingan keefektifan pendekatan pembelajaran realistik dan saintifik terhadap prestasi belajar kemampuan penalaran matematis, dan minat belajar.

\section{METODE}

Penelitian ini menggunakan metode eksperimen semu (quasi eksperimental). Desain yang digunakan adalah desain pretest-posttest non-equivalent group design. Tiga kelompok yang sudah ada diberi pretest, diberi perlakuan (treatment) dan diberi posttest. Ketiga kelompok dipilih karena setara dengan karakteristik siswa dan mendekati sama, yang membedakan adalah pemberian perlakuan pembelajaran dengan pendekatan realistik, pendekatan saintifik, dan pembelajaran konvensional.

Rancangan eksperimen yang digunakan berdasarkan adalah Nonequivalent control group design adalah:

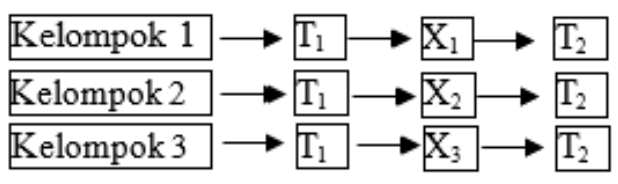

Gambar 1. Pretest-Posttest Nonequivalent Group Design

Keterangan:

$\mathrm{T}_{1}$ : pretest kelompok realistik, saintifik, dan konvensional.

$\mathrm{T}_{2}$ : posttest kelompok realistik, saintifik, dan konvensional.

$\mathrm{X}_{1}$ : Penerapan pendekatan realistik.

$\mathrm{X}_{2}$ : Penerapan pendekatan saintifik.

$\mathrm{X}_{3}$ : Pembelajaran konvensional

Langkah-langkah yang dilakukan dalam penelitian eksperimen berupa pemilihan tiga kelompok (kelas) secara acak untuk menentukan kelompok pertama, kedua, dan ketiga, kemudian memberikan pretest pada waktu yang bersamaan. Selanjutnya memberikan perlakuan pembelajaran dengan menggunakan pendekatan matematika realistik di kelompok pertama, pendekatan saintifik di kelompok kedua, dan pembelajaran konvensional pada kelompok ketiga. Kemudian dilanjutkan dengan memberikan posttest pada ketiga kelompok dalam waktu yang relatif bersamaan untuk mengetahui prestasi belajar, kemampuan penalaran matematis, dan minat belajar.

Penelitian ini dilakukan di SMP Negeri 1 Kelumpang hilir. Penelitian ini dilaksanakan pada siswa kelas IX semester 2 tahun pelajaran 2015/2016. Penelitian ini dilaksanakan sebanyak tujuh kali pertemuan. Populasi dalam penelitian ini adalah seluruh siswa kelas IX SMP Negeri 1 Kelumpang Hilir tahun ajaran 2015/2016, terdiri atas 6 kelas. Dengan menggunakan teknik pengundian secara acak dari 6 kelas, diperoleh tiga kelas yaitu kelas IX-A dengan pendekatan realistik, kelas IX-B dengan pendekatan saintifik, dan kelas IX-C dengan pembelajaran konvensional.

Terdapat dua macam variabel dalam penelitian ini, yaitu variabel independen (variabel bebas) dan variabel dependen (variabel terikat). Variabel bebas yaitu pendekatan pembelajaran yang terdiri dari atas pendekatan matematika realistik $\left(\mathrm{X}_{1}\right)$, pendekatan saintifik $\left(\mathrm{X}_{2}\right)$, dan pembelajaran konvensional $\left(\mathrm{X}_{3}\right)$. Variabel terikat yaitu prestasi belajar, kemampuan penalaran matematis, dan minat belajar.

Teknik pengumpulan data dalam penelitian ini adalah tes dan angket berupa tes awal (pretest) dan tes akhir (posttest). Sedangkan 


\section{Jurnal Riset Pendidikan Matematika, 4 (1), 2017 - 5}

Aji Wibowo

instrumen penelitian yang digunakan dalam penelitian ini adalah instrumen tes prestasi belajar, tes kemampuan penalaran matematis, dan pengisian angket minat belajar.

Dari segi validitas isi, instrumen tes dan angket layak digunakan menurut ahli. Dari segi validitas konstruk, berdasarkan hasil analisis faktor pada angket minat belajar siswa instrumen dinyatakan valid. Reliabilitas tes prestasi belajar terdiri atas tes pilihan ganda yaitu 0,713 dan 0,765 dengan Standar Error Measurement (SEM) sebesar 9,6 dan 8,97. Reliabilitas tes kemampuan penalaran matematis adalah 0,766 dan 0,773 dengan SEM sebesar 7,6 dan 7,842. Reliabilitas angket minat belajar adalah 0,893 dengan SEM sebesar 5,062.

Untuk mengetahui keefektifan pembelajaran dengan pendekatan realistik, saintifik dan konvensional pada masing-masing variabel prestasi belajar, kemampuan penalaran matematis dan minat belajar siswa dilakukan uji $\mathrm{t}$ one sample. Ditetapkan standar untuk variabel prestasi belajar dan kemampuan penalaran matematis dikatakan efektif jika lebih dari KKM sekolah untuk mata pelajaran matematika yaitu 70, sedangkan untuk variabel minat belajar dikatakan efektif jika telah mencapai kategori tinggi (skor lebih dari 102).

Untuk mengetahui keefektifan masingmasing pendekatan pembelajaran terhadap prestasi belajar, kemampuan penalaran matematis dan minat belajar matematika siswa maka diuji hipotesis sebagai berikut, dengan menetapkan kelas ke-1 adalah kelas konvensional, kelas ke-2 adalah kelas realistik kelas ke-3 adalah kelas saintifik, variabel ke-1 adalah prestasi belajar, variabel ke-2 adalah kemampuan penalaran matematis, dan variabel ke-3 adalah minat belajar matematika.

Untuk menjawab apakah pendekatan realistik dan saintifik serta pembelajaran konvensional efektif terhadap prestasi belajar apabila rata-rata lebih dari sama dengan 70 . Secara statistik, hipotesis di atas dapat dituliskan sebagai berikut :

$\mathrm{H}_{01}: \mu_{1 \mathrm{i}} \leq 70, \mathrm{i}=1,2,3$

$\mathrm{H}_{11}: \mu_{1 \mathrm{i}}>70, \mathrm{i}=1,2,3$

Dimana $\mu_{11}=$ rata-rata prestasi belajar siswa pada pembelajaran konvensional, $\mu_{12}=$ rata-rata prestasi belajar siswa pada pendekatan pembelajaran realistik, dan $\mu_{13}=$ rata-rata prestasi belajar siswa pada pendekatan sainifik.

Untuk menjawab apakah pendekatan realistik dan saintifik serta pembelajaran konven- sional efektif terhadap kemampuan penalaran matematis apabila rata-rata lebih dari sama dengan 70. Secara statistik, hipotesis tersebut dapat dituliskan sebagai berikut :

$\mathrm{H}_{02}: \mu_{2 \mathrm{i}} \leq 70, \mathrm{i}=1,2,3$

$\mathrm{H}_{12}: \mu_{2 \mathrm{i}}>70, \mathrm{i}=1,2,3$

Dimana $\mu_{21}=$ rata-rata kemampuan penalaran matematis pada pembelajaran konvensional, $\mu_{22}=$ rata-rata kemampuan penalaran matematis pada pendekatan pembelajaran realistik, dan $\mu_{23}=$ rata-rata kemampuan penalaran matematis pada pendekatan sainifik.

Untuk menjawab apakah pendekatan realistik dan saintifik serta pembelajaran konvensional efektif terhadap minat belajar apabila rata-rata lebih dari sama dengan 102. Secara statistik, hipotesis di atas dapat dituliskan sebagai berikut :

$\mathrm{H}_{03}: \mu_{3 i} \leq 102, \mathrm{i}=1,2,3$

$\mathrm{H}_{13}: \mu_{3 i}>102, \mathrm{i}=1,2,3$

Dimana $\mu_{31}=$ rata-rata minat belajar siswa pada pembelajaran konvensional, $\mu_{32}=$ rata-rata minat belajar siswa pada pendekatan pembelajaran realistik, dan $\mu_{33}=$ rata-rata minat belajar siswa pada pendekatan sainifik.

Statistik uji yang digunakan untuk menguji hipotesis di atas adalah uji one sample $t$-test dengan formula sebagai berikut:

$t=\frac{\bar{x}-\mu_{0}}{\frac{5}{\sqrt{n}}}$

Keterangan:

$\bar{x}=$ nilai rata-rata yang diperoleh

$\mu_{0}=$ nilai yang dihipotesiskan

$\mathrm{S}=$ standar deviasi sampel

$\mathrm{n}$ = banyak anggota sampel.

$\mathrm{H}_{\mathrm{o}}$ ditolak jika nilai $\mathrm{t}_{\text {hitung }}>\mathrm{t}_{\text {tabel }}$.

Untuk menyelidiki pengaruh pendekatan pembelajaran realistik, saintifik dan konvensional terhadap prestasi belajar, kemampuan penalaran matematis dan minat belajar siswa dilakukan uji MANOVA planned comparisons dengan kontras Helmert. Dalam kontras Helmert ada 2 hipotesis yang diuji, yaitu sebagai berikut.

1. $\widehat{\Psi_{1}}=\mu_{1}-\frac{\mu_{2}+\mu_{g}}{2}$ GPS (1)

2. $\widetilde{\Psi_{2}}=\mu_{2}-\mu_{3} \quad$ GPS (2)

Pada kontras Helmert GPS 1 untuk menjawab apakah ada pengaruh pendekatan realistik dan saintifik terhadap prestasi belajar, kemampuan penalaran matematis, dan minat belajar adalah sebagai berikut. 
$H_{04}$ : Tidak ada pengaruh kelas pendekatan pembelajaran realistik dan saintifik terhadap prestasi belajar, kemampuan penalaran matematis dan minat belajar siswa.

$H_{14}:$ Ada pengaruh kelas pendekatan pembelajaran realistik dan saintifik terhadap prestasi belajar, kemampuan penalaran matematis dan minat belajar siswa.

Secara statistik, hipotesis tersebut dapat disimbolkan sebagai berikut.

$\mathrm{H}_{04}: \Psi_{1}=\mu_{1}-\frac{\mu_{2}+\mu_{g}}{2}=0$

$\mathrm{H}_{14}: \Psi_{1}=\mu_{1}-\frac{\mu_{2}^{2}+\mu_{p}}{2} \neq 0$

dengan $\mu_{1}=\left(\begin{array}{c}\mu_{111} \\ \mu_{n 1} \\ \mu_{s 1}\end{array}\right) ; \mu_{2}=\left(\begin{array}{c}\mu_{12} \\ \mu_{28} \\ \mu_{s 2}\end{array}\right), \mu_{3}=\left(\begin{array}{c}\mu_{18} \\ \mu_{n s} \\ \mu_{g s}\end{array}\right)$

Dikatakan berpengaruh apabila rata-rata pendekatan pembelajaran realistik dan saintifik tidak sama dari rata-rata pembelajaran konvensional.

Pada kontras Helmert GPS 2 untuk menjawab perbedaan keefektifan antara pendekatan realistik dan saintifik terhadap prestasi belajar, kemampuan penalaran matematis, dan minat belajar adalah sebagai berikut.

$H_{05}$ : Tidak ada perbedaan keefektifan antara pendekatan pembelajaran realistik dibandingkan dengan saintifik terhdap prestasi belajar, kemampuan penalaran matematis dan minat belajar siswa.

$\mathrm{H}_{15}$ : Ada perbedaan keefektifan antara pendekatan pembelajaran realistik dibandingkan dengan saintifik terhadap prestasi belajar, kemampuan penalaran matematis dan minat belajar siswa.

Secara statistik, hipotesis di atas dapat disimbolkan sebagai berikut.

$\mathrm{H}_{05}: \widetilde{\Psi_{2}}=\mu_{2}-\mu_{3}=0$

$\mathrm{H}_{15}: \widehat{\Psi_{2}}=\mu_{2}-\mu_{3} \neq 0$

Statistik uji yang akan digunakan untuk menguji hipotesis di atas adalah sebagai berikut.

$$
T^{2}=\left(\sum_{\mathrm{i}=1}^{\mathrm{k}} \frac{\mathrm{c}_{\mathrm{i}}^{2}}{\mathrm{n}_{\mathrm{i}}}\right)^{-1} \widehat{\Psi}^{\prime} \mathrm{S}^{-1} \widehat{\Psi}
$$

dengan:

$\mathrm{T}^{2}=$ Hotelling's Trace

$\mathrm{n}_{\mathrm{i}}=$ banyak anggota sampel $\mathrm{i}$

$\mathrm{k}=$ banyaknya kelompok

$\mathrm{c}_{\mathrm{i}}=$ kontras

$\mathrm{S}^{-1}=$ invers matriks kovariansi.

$\widehat{\Psi}=$ estimasi rata-rata vektor kontras
Perhitungan hasil analisis untuk GPS kemudian ditransformasikan untuk memperoleh nilai dari distribusi $\mathrm{F}$ dengan formula sebagai berikut.

Uji Multivariat

$F=\frac{N-K-p+1}{(N-K) p} T^{2}$

Dengan kriteria, jika $F_{\text {hitung }}>F_{\text {tabel }}$, maka $H_{0}$ ditolak.

Uji Univariat

$F=\frac{\hat{\Psi}^{2} / \sum_{i=1}^{k} \frac{e_{i}^{2}}{n_{i}}}{M S_{w}}$

Dengan kriteria, jika $F_{\text {hitung }}>F_{\text {tabel }}$, maka $H_{0}$ ditolak.

Perhitungan dengan formula tersebut, dilakukan dengan bantuan syntax SPSS 22 for windows melalui Helmert Contrast pada taraf signifikansi $5 \%$, dengan kriteria jika nilai signifikansi kurang dari 0,05 maka $H_{0}$ ditolak.

\section{HASIL DAN PEMBAHASAN}

Data yang dideskripsikan berupa hasil pretest dan posttest prestasi belajar, kemampuan penalaran matematis, dan minat belajar yang dikumpulkan sebelum dan sesudah diberi perlakuan. Data hasil tes prestasi belajar pada kelas realistik, saintifik, dan konvensional dideskripsikan pada Tabel 1 .

Tabel 1. Data Prestasi Belajar pada Pretest

\begin{tabular}{cccc}
\hline \multirow{2}{*}{ Deskripsi } & \multicolumn{3}{c}{ Kelas } \\
\cline { 2 - 4 } & Realistik & Saintifik & Konven \\
\hline Rata-rata & 40,781 & 39,848 & 37,206 \\
Varians & 151,789 & 100,758 & 141,199 \\
Standar dev & 12,320 & 10,038 & 11,883 \\
Min teo & 0 & 0 & 0 \\
Nilai min & 15,00 & 20,00 & 10,00 \\
Maks teo & 100 & 100 & 100 \\
Nilai maks & 65,00 & 60,00 & 60,00 \\
\hline
\end{tabular}

Tabel 2. Data Prestasi Belajar pada Posttest

\begin{tabular}{cccc}
\hline \multirow{2}{*}{ Deskripsi } & \multicolumn{3}{c}{ Kelas } \\
\cline { 2 - 4 } & Realistik & Saintifik & Konven \\
\hline Rata-rata & 85,156 & 75,303 & 55,735 \\
Varians & 86,265 & 62,405 & 68,382 \\
Standar dev & 9,288 & 7,900 & 8,269 \\
Min teo & 0 & 0 & 0 \\
Nilai min & 60,00 & 60,00 & 35,00 \\
Maks teo & 100 & 100 & 100 \\
Nilai maks & 100,00 & 90,00 & 70,00 \\
\hline
\end{tabular}

Tabel 1 menunjukkan bahwa nilai ratarata pretest pada ketiga kelas relatif sama yaitu pada kelas realistik 40,781 kelas saintifik 39,848 dan kelas kontrol 37,206. Dari ketiga kelas yang 
digunakan dalam penelitian ini, nilai tertinggi pretest yang dicapai siswa adalah 65,00 dan nilai terendah 10,00.

Berdasarkan Tabel 2, rata-rata nilai posttest kelas realistik, kelas saintifik dan kelas kontrol, berturut-turut adalah 85,156; 75,303 dan 55,735. Secara deskriptif, hasil posttest kelas realistik lebih tinggi dibanding kelas saintifik dan kontrol, dan hasil posttest saintifik juga lebih tinggi dibanding kelas kontrol.

Tabel 3. Data Kemampuan Penalaran Matematis pada Pretest

\begin{tabular}{cccc}
\hline \multirow{2}{*}{ Deskripsi } & \multicolumn{3}{c}{ Kelas } \\
\cline { 2 - 4 } & Realistik & Saintifik & Konven \\
\hline Rata-rata & 28,82 & 27,27 & 28,59 \\
Varians & 111,38 & 76,42 & 60,11 \\
Standar dev & 10,55 & 8,74 & 7,75 \\
Min teo & 0 & 0 & 0 \\
Nilai min & 11,11 & 11,11 & 8,33 \\
Maks teo & 100 & 100 & 100 \\
Nilai maks & 50,00 & 55,56 & 47,22 \\
\hline
\end{tabular}

Tabel 3 menunjukkan bahwa nilai ratarata pretest pada ketiga kelas relatif sama yaitu pada kelas realistik 28,82; kelas saintifik 27,27 dan kontrol 28,59. Dari ketiga kelas yang digunakan dalam penelitian ini, nilai tertinggi pretest yang dicapai siswa adalah 55,56 dan nilai terendah 8,33 .

Tabel 4. Data Kemampuan Penalaran Matematis pada Posttest

\begin{tabular}{cccc}
\hline \multirow{2}{*}{ Deskripsi } & \multicolumn{3}{c}{ Kelas } \\
\cline { 2 - 4 } & Realistik & Saintifik & Konven \\
\hline Rata-rata & 77,69 & 71,30 & 47,22 \\
Varians & 63,96 & 94,84 & 119,25 \\
Standar dev & 8,00 & 9,74 & 10,92 \\
Min teo & 0 & 0 & 0 \\
Nilai min & 58,33 & 47,22 & 30,56 \\
Maks teo & 100 & 100 & 100 \\
Nilai maks & 91,67 & 88,89 & 75,00 \\
\hline
\end{tabular}

Tabel 5. Data Minat Belajar Sebelum Perlakuan

\begin{tabular}{cccc}
\hline \multirow{2}{*}{ Deskripsi } & \multicolumn{3}{c}{ Kelas } \\
\cline { 2 - 4 } & Realistik & Saintifik & Konven \\
\hline Rata-rata & 89,47 & 86,67 & 86,47 \\
Varians & 156,71 & 259,98 & 260,07 \\
Standar dev & 12,52 & 16,12 & 16,13 \\
Min teo & 30 & 30 & 30 \\
Nilai min & 65,00 & 55,00 & 53,00 \\
Maks teo & 150 & 150 & 150 \\
Nilai maks & 115,00 & 119,00 & 119,00 \\
\hline
\end{tabular}

Berdasarkan Tabel 4, rata-rata nilai posttest kelas realistik, kelas saintifik dan kelas kontrol, berturut-turut adalah 77,69; 71,30 dan 47,22 . Secara deskriptif, hasil posttest kelas realistik lebih tinggi dibanding kelas saintifik dan kontrol, dan hasil posttest saintifik juga lebih tinggi daripada kelas kontrol.

Berdasarkan Tabel 5, rata-rata minat belajar siswa sebelum diberikan perlakuan pada kelas realistik 89,47; kelas saintifik 86,67 dan kelas kontrol 86,47. Rata-rata skor minat belajar sebelum perlakuan pada setiap kelas berada pada interval skor $78<\bar{M} \leq 102$ yaitu termasuk pada kriteria sedang.

Tabel 6. Deskripsi Data Minat Belajar Sesudah Perlakuan

\begin{tabular}{cccc}
\hline \multirow{2}{*}{ Deskripsi } & \multicolumn{3}{c}{ Kelas } \\
\cline { 2 - 4 } & Realistik & Saintifik & Konven \\
\hline Rata-rata & 116,72 & 107,76 & 98,53 \\
Varians & 128,47 & 82,06 & 99,59 \\
Standar dev & 11,33 & 9,06 & 9,98 \\
Min teo & 30 & 30 & 30 \\
Nilai min & 93,00 & 89,00 & 80,00 \\
Maks teo & 150 & 150 & 150 \\
Nilai maks & 138,00 & 125,00 & 115,00 \\
\hline
\end{tabular}

Rata-rata skor minat belajar siswa setelah diberikan perlakuan pada kelas realistik 116,72; kelas saintifik 107,76 dan kelas kontrol 98,53. Rata-rata skor minat setelah perlakuan pada kelas realistik dan saintifik berada pada interval skor $102<\bar{M} \leq 126$ yaitu pada termasuk pada kriteria tinggi, sedangkan untuk kelas konvensonal pada interval $78<\bar{M} \leq 102$ yaitu pada kategori sedang. Terlihat bahwa pada ketiga kelas terjadi peningkatan skor minat belajar matematika jika dibandingkan antara skor sebelum perlakuan dengan rata-rata skor setelah perlakuan.

Uji normalitas dan homogenitas data prestasi belajar, kemampuan penalaran matematis, dan minat belajar siswa untuk sebelum dan setelah perlakuan, baik untuk kelas realistik, kelas saintifik, dan kelas konvensional secara berturut-turut bisa dilihat pada Tabel 7 dan Tabel 8.

Tabel 7. Hasil Uji Normalitas

\begin{tabular}{ccc}
\hline Kelas & $\begin{array}{c}d_{i}^{2} \text { Sebelum } \\
\text { Perlakuan }\end{array}$ & $\begin{array}{c}d_{i}^{2} \text { Setelah } \\
\text { Perlakuan }\end{array}$ \\
\hline Realistik & $43,75 \%$ & $50 \%$ \\
Saintifk & $45,45 \%$ & $48,48 \%$ \\
Konven & $52,94 \%$ & $50 \%$ \\
\hline
\end{tabular}

Tabel 7 memperlihatkan bahwa sekitar 50\% data mempunyai nilai $d_{i}^{2}<X_{(3 ; 0,5)}^{2}$. Dengan kata lain, data prestasi belajar, data kemampuan penalaran matematis, dan minat belajar siswa untuk sebelum dan setelah perlakuan, baik untuk kelas realistik, kelas saintifik, dan kelas konvensional sudah memenuhi asumsi normalitas. 
Tabel 8. Hasil Uji Homogenitas

\begin{tabular}{ccc}
\hline & Sebelum perlakuan & Setelah perlakuan \\
\hline Box's $M$ & 12,668 & 16,177 \\
$F$ & 1,008 & 1,287 \\
Sig. & 0,438 & 0,218 \\
\hline
\end{tabular}

Berdasarkan Tabel 8, diperoleh informasi bahwa nilai signifikansi $F$ lebih besar dari 0,05 atau dengan kata lain, data prestasi belajar, kemampuan penalaran matematis, dan minat belajar siswa untuk sebelum dan setelah perlakuan sudah memenuhi asumsi homogenitas.

Keefektifan pembelajaran diuji dengan $\mathrm{t}$ one sample, dengan kriteria jika $\mathrm{t}_{\text {hitung }}>\mathrm{t}_{\text {tabel }}$ maka pembelajaran tersebut dikatakan efektif untuk variabel yang ditentukan. Hasil perhitungan dapat dilihat pada Tabel 9.

Tabel 9. Hasil Uji t One Sample

\begin{tabular}{ccccc}
\hline Var & Kelas & $\boldsymbol{t}_{\text {hitung }}$ & $\boldsymbol{t}_{\text {tabel }}$ & Ket \\
\hline \multirow{4}{*}{ Prestasi } & Realistik & 9,231 & 1,696 & Efektif \\
& Saintifik & 3,856 & 1,694 & Efektif \\
& Konven & $-10,058$ & 1,692 & Tidak \\
& & & & efektif \\
& Realistik & 5,440 & 1,696 & Efektif \\
Penalaran & Saintifik & 0,765 & 1,694 & Tidak \\
& & & & efektif \\
& Konven & $-12,163$ & 1,692 & Efektif \\
& Realistik & 7,346 & 1,696 & Efektif \\
Minat & Saintifik & 3,651 & 1,694 & Efektif \\
& Konven & $-2,028$ & 1,692 & Tidak \\
& & & & efektif \\
\hline
\end{tabular}

Berdasarkan Tabel 9. diperoleh informasi bahwa pendekatan realistik efektif terhadap prestasi belajar, kemampuan penalaran matematis dan minat belajar. Hal ini sejalan dengan pendapat Rangkuti (2015, p. 14) bahwa pembelajaran dengan menggunakan pendekatan matematika realistik dapat memberi kesempatan siswa untuk meningkatkan kemampuanya. Selanjutnya menurut Zaini \& Marsigit (2014, p. 152) yang mengungkapkan bahwa pembelajaran dengan pendekatan matematika realistik lebih baik dari pembelajaran konvensional ditinjau dari kemampuan penalaran dan komunikasi matematik siswa.

Pembelajaran dengan pendekatan saintifik efektif terhadap prestasi belajar dan minat belajar siswa tetapi tidak efektif terhadap kemampuan penalaran matematis. Hal ini sejalan dengan Efriana (2014, p. 108) yang menyatakan bahwa penerapan pendekatan saintifk dapat meningkatkan prestasi belajar siswa. Selanjutnya menurut Suhendar \& Widjajanti (2016) yang menyatakan bahwa pendekatan saintifik efektif ditinjau dari prestasi belajar, minat dan rasa percaya diri terhadap matematika siswa. Untuk kemampuan penalaran matematis tidak sejalan dengan kajian teori karena terdapat beberapa keterbatasan seperti jam pelajaran yang tidak dapat diubah saat penelitian.

Untuk pembelajaran konvensional tidak efektif terhadap prestasi belajar, kemampuan penalaran matematis, dan minat belajar siswa. Hal ini sejalan dengan pendapat Suryanto (2010, p. 49) pembelajaran konvensional merupakan pembelajaran yang berorientasi pada guru, siswa menerima materi pelajaran secara pasif dan guru yang aktif menyampaikan pengetahuan dan yang dipentingkan adalah produk yang disebut prestasi bukan proses dan pemahaman.

Ada tidaknya pengaruh pendekatan pembelajaran realistik dan saintifik terhadap prestasi belajar kemampuan penalaran matematis, dan minat belajar diuji kontras Helmert. Hasil perhitungan dengan kontras Helmert untuk GPS 1 disajikan pada Tabel 10. Rata-rata nilai kelas realistik dan saintifik dengan kelas konvensional disajikan pada Tabel 11.

Tabel 10. Hasil Uji Kontras Helmert (GPS 1)

\begin{tabular}{ccccc}
\hline Uji & Var. & $\mathbf{F}_{\text {hitung }}$ & $\mathbf{F}_{\text {tabel }}$ & Sig. \\
\hline \multicolumn{2}{c}{ Multivariat } & 16,6 & 2,7 & 0,0 \\
\hline \multirow{3}{*}{ Univariat } & Prestasi & 18,6 & 3,9 & 0,0 \\
& Penalaran & 17,8 & 3,9 & 0,0 \\
& Minat & 4,1 & 3,9 & 0,0 \\
\hline
\end{tabular}

Tabel 11. Nilai Rata-rata Kelas Realistik dan Saintifik dengan Kelas Konvensional

\begin{tabular}{ccc}
\hline Variabel & $\begin{array}{c}\text { Rata-rata Real \& } \\
\text { Sain }\end{array}$ & $\begin{array}{c}\text { Rata-rata } \\
\text { Konv }\end{array}$ \\
\hline Prestasi & 80,23 & 55,74 \\
Penalaran & 74,49 & 47,22 \\
Minat & 112,24 & 98,53 \\
\hline Pada & Tabel 10. menunjukkan bahwa
\end{tabular}
terdapat pengaruh pendekatan pembelajaran realistik dan saintifik terhadap prestasi belajar, kemampuan penalaran matematis dan minat belajar siswa. Sedangkan untuk Tabel 11. Menunjukkan bahwa rata-rata nilai kelas realistik dan saintifik dibanding kelas konvensional lebih tinggi yang berarti kelas saintifik dan realistik lebih efektif.

Pendekatan realistik dan saintifik merupakan pendekatan yang berbasis kontruktivis dimana siswa aktif dalam mengembangkan pengetahuanya sendiri. (Hadi, 2005, p. 14) mengemukakan bahwa prinsip-prinsip kontrukstivis dalam pembelajaran antara lain (1) pengetahuan dibangun oleh siswa sendiri, baik secara perso- 


\section{Jurnal Riset Pendidikan Matematika, 4 (1), 2017 - 9}

Aji Wibowo

nal maupun sosial, (2) pengetahuan tidak dapat dipindahkan dari guru ke siswa, kecuali hanya dengan keaktifan siswa sendiri untuk menalar, (3) murid aktif mengkonstruksi terus menerus, sehingga selalu terjadi perubahan konsep menuju konsep yang lebih rinci, lengkap, serta sesuai dengan konsep ilmiah. Dari prinsip kontruktivis tersebut diketahui bahwa pembelajaran berbasis kontrukstivis dapat membuat siswa membangun sendiri pengetahuanya sehingga prestasi dan kemampuan penalaranya bisa meningkat.

Perbandingan keefektifan pendekatan pembelajaran realistik dengan saintifik terhadap prestasi belajar, kemampuan penalaran matematis, dan minat belajar diuji dengan kontras Helmert. Hasil perhitungan dengan kontras Helmert untuk GPS 2 disajikan pada Tabel 12. Rata-rata nilai kelas realistik dan kelas saintifik disajikan pada Tabel 13.

Tabel 12. Hasil Uji Kontras Helmert (GPS 2)

\begin{tabular}{ccccc}
\hline Uji & Var. & $\mathbf{F}_{\text {hitung }}$ & $\mathbf{F}_{\text {tabel }}$ & Sig. \\
\hline Multivariat & 16,9 & 2,7 & 0,0 \\
\hline \multirow{3}{*}{ Univariat } & Prestasi & 21,9 & 3,9 & 0,0 \\
& Penalaran & 7,1 & 3,9 & 0,0 \\
& Minat & 12,7 & 3,9 & 0,0 \\
\hline
\end{tabular}

Tabel 13. Nilai Rata-rata Kelas Realistik dan Kelas Saintifik

\begin{tabular}{ccc}
\hline Variabel & Rata-rata Real & Rata-rata Sain \\
\hline Prestasi & 85,16 & 75,30 \\
Penalaran & 77,69 & 71,30 \\
Minat & 116,72 & 107,76 \\
\hline
\end{tabular}

Berdasarkan Tabel 12. diketahui bahwa secara multivariat dan univariat $F_{\text {hitung }}>F_{\text {tabel }}$ yang berarti ada perbedaan keefektifan antara kelas realistik dan saintifik. Kemudian, berdasarkan Tabel 13. diketahui bahwa rata-rata realistik lebih tinggi daripada kelas saintifik, yang berarti bahwa kelas realistik lebih efektif dibandingkan kelas saintifik.

Hasil penelitian ini sesuai dengan hipotesis penelitian bahwa pendekatan realistik lebih efektif dibandingkan dengan pendekatan saintifik terhadap prestasi belajar, kemampuan penalaran matematis dan minat belajar siswa. Walaupun kedua pendekatan ini berbasis kontrukstivis dan sama-sama efektif terhadap prestasi belajar, namun hasil penelitian pada variabel prestasi belajar untuk kelas realistik lebih unggul dibandingkan dengan saintifik. Pada pendekatan realistik ada dua langkah yang dapat menyebabkan prestasi belajar meningkat yaitu pada langkah melakukan matematika vertikal dan mengkomunikasikan secara interaktif, sedangkan pada pendekatan saintifik hanya pada langkah mengkomunikasikan.

Pada pendekatan realistik ada empat langkah yang dapat menyebabkan kemampuan penalaran matematis meningkat yaitu pada langkah mengawali masalah yang kontekstual, melakukan matematika horizontal, melakukan matematika vertikal, dan melakukan refleksi sedangkan pada pendekatan saintifik juga terdapat empat langkah yang dapat meningkatkan kemampuan penalaran yaitu langkah mengamati, mengumpulkan informasi, mengasosiasi dan mengomunikasikan. Namun hasil penelitian menunjukkan bahwa pendekatan realistik lebih unggul dibandingkan dengan pendekatan saintifik.

Begitu juga untuk minat belajar, untuk pendekatan realistik terdapat tiga yaitu mengawali masalah yang kontekstual, melakukan matematika vertikal dan melakukan refleksi sedangkan untuk saintifik pada langkah mengamati, menanya dan mengumpulkan informasi. Namun hasil penelitian menunjukkan bahwa pendekatan realistik lebih unggul dibandingkan dengan pendekatan saintifik.

\section{SIMPULAN}

Pendekatan pembelajaran realistik efektif terhadap prestasi belajar, kemampuan penalaran matematis, dan minat belajar siswa; dan pendekatan pembelajaran saintifik efektif terhadap prestasi belajar, dan minat belajar siswa tetapi tidak efektif terhadap kemampuan penalaran matematis, sedangkan pembelajaran konvensional tidak efektif terhadap prestasi belajar, kemampuan penalaran matematis, dan minat belajar. Pendekatan pembelajaran realistik dan saintifik berpengaruh dan lebih efektif dibandingkan dengan pembelajaran konvensional terhadap prestasi belajar, kemampuan penalaran matematis, dan minat belajar. Pendekatan pembelajaran realistik lebih efektif daripada saintifik terhadap prestasi belajar, kemampuan penalaran dan minat belajar siswa.

\section{DAFTAR PUSTAKA}

Crompton, H., \& Traxler, J. (2015). Mobile learning and mathematics: foundations, design, and case studies.

D'Amico, J., \& Gallaway, K. (2010). Differentiated instruction for the middle school language arts teacher: Activities and strategies for an inclusive classroom. San Francisco: Jossey-Bass.

Dewey, J. (1975). Interest and effort in 
education. Southern Illinois University Press.

Efriana, F. (2014). Penerapan pendekatan scientific untuk meningkatkan hasil belajar siswa kelas VII MTSn palu barat pada materi keliling dan luas daerah layang-layang. Jurnal Elektronik Pendidikan Matematika Tadulako, 1(2). Retrieved from http://jurnal.untad.ac.id/jurnal/index.php/J EPMT/article/view/3219

Gravemeijer, K. (1994). Developing realistic mathematics education = ontwikkelen van realistisch reken/wiskundeonderwijs (met een samenvatting in het Nederlands). Utrecht: Freudenthal Institute.

Hadi, S. (2005). Pendidikan matematika realistik dan implementasinya. Banjarmasin: Tulip.

Hosnan, M., \& Sikumbang, R. (2014). Pendekatan saintifik dan kontekstual dalam pembelajaran abad 21: Kunci sukses implementasi kurikulum 2013. Bogor: Ghalia Indonesia.

Lovat, T., Dally, K., Clement, N., \& Toomey, R. (2011). Values Pedagogy and Student Achievement. Dordrecht: Springer Netherlands. http://doi.org/10.1007/97894-007-1563-9

Menteri Pendidikan dan Kebudayaan Republik Indonesia. Peraturan menteri pendidikan dan kebudayaan No.58 tentang kurikulum 2013 sekolah menengah pertama/madrasah tsanawiyah, Peraturan Menteri Pendidikan Nasional (2014). Indonesia.

Menteri Pendidikan Nasional. Peraturan Menteri Pendidikan Nasional RI nomor 22, tahun 2006, tentang standar isi intuk satuan pendidikan dan menengah, Peraturan Menteri Pendidikan Nasional (2006).

Nitko, A. J., \& Brookhart, S. M. (2011). Educational assessment of students. New Jersey: Pearson/Allyn \& Bacon.

Preiss, D. D., \& Sternberg, R. J. (2010). Innovations in educational psychology: Perspectives on learning, teaching, and human development. New York, NY: Springer Publishing Company. Retrieved from http://www.imd.inder.cu/adjuntos/article/ 460/Innovations in Educational
Psychology.pdf

Rangkuti, A. N. (2015). Developing a learning trajectory on fraction topics by using realistic mathematics education approach in primary school. IOSR Journal of Research \& Method in Education Ver. III, 5(5), 2320-7388. http://doi.org/10.9790/7388-05531316

Sugiman. (2011). Peningkatan pembelajaran matematika dengan menggunakan pendekatan matematika realistik. Yogyakarta. Retrieved from http://staff.uny.ac.id/sites/default/files/tm p/2011_PPM_Iceberg_0.pdf

Suhendar, U., \& Widjajanti, D. B. (2016). Komparasi keefektifan saintifik dan PMRI ditinjau dari prestasi, minat, dan percaya diri siswa kelas VII. PYTHAGORAS: Jurnal Pendidikan Matematika, 11(1), 91-101. http://doi.org/10.21831/PG.V1111.9674

Suryanto. (2010). Sejarah pendidikan matematika realistik Indonesia (PMRI). Yogyakarta: Tidak Diterbitkan.

The National Council of Teachers of Mathematics. (2000). NCTM principles and standards for school mathematics,. Association Drive, Reston, VA: Library of Congres Cataloguing-in-Publication Data. Retrieved from https://www.nctm.org/store/Products/NC TM-Principles-and-Standards-for-SchoolMathematics,-Full-Edition-(PDF)/

The National Council of Teachers of Mathematics. (2009). Focus in high school mathematics: Reasoning and sense making. Reston, VA: National Council of Teacher of Mathematics. Retrieved from http://www.nctm.org

Tipps, S., Johnson, A., \& Kennedy, L. M. (2008). Guiding children's learning of mathematics (11 ed). Belmont: Wadsworth/Cengage Learning.

Zaini, A., \& Marsigit, M. (2014). Perbandingan keefektifan pembelajaran matematika dengan pendekatan matematika realistik dan konvensional ditinjau dari kemampuan penalaran dan komunikasi matematik siswa. Jurnal Riset Pendidikan Matematika, $\quad 1(2), \quad 152$. http://doi.org/10.21831/jrpm.v1i2.2672. 